\title{
Effect of Salinity on Germination, Seedling Growth and Acid Phosphatase Activity in Lettuce
}

\author{
Nawel Nasri*\#, Issam Saïdi*, Rym Kaddour, Mokhtar Lachaâl \\ Physiologie et Biochimie de la Tolérance au Sel des Plantes, Faculté des Sciences de Tunis, Campus \\ Universitaire, Tunis, Tunisia \\ Email: " nasrinawel@yahoo.fr
}

Received 14 November 2014; revised 2 December 2014; accepted 15 December 2014

Copyright @ 2015 by authors and Scientific Research Publishing Inc.

This work is licensed under the Creative Commons Attribution International License (CC BY). http://creativecommons.org/licenses/by/4.0/

c) (i) Open Access

\section{Abstract}

The impact of salt stress ( $\mathrm{NaCl} 100 \mathrm{mM}$ ) on two lettuce varieties Romaine and Vista was conducted at germination and early seedling stages. The seeds of lettuce varieties were provided by the Seed Laboratory of Tunisian Ministry of Agriculture. The seeds were germinated in Petri dishes with double filter paper in distilled water (control) or $\mathrm{NaCl}$ solution $(100 \mathrm{mM})$ for 5 days. The result showed that salinity significantly affected percentage and rate of germination in Vista variety but $100 \%$ of germination was found in Romaine. Length and fresh weight of root and shoot were reduced significantly with salt treatment in two lettuce varieties. Regarding biochemical analysis, acid phosphatase activity in root increased in Romaine and decreased in Vista. In shoot, this activity showed no difference with the control in the two varieties. However in cotyledons, and during 24 hours after germination, salinity decreased acid phosphatase activity in both varieties whereas in the later hours (48 - $96 \mathrm{~h}$ ) this activity reached the value of the control in Romaine and Vista.

\section{Keywords}

Acid Phosphatase, Germination, Lettuce, Salinity, Seedling

\section{Introduction}

High salinity is a common abiotic stress factor that seriously affects crop production in some parts of the world, particularly in arid and semi-arid regions [1]. Germination is one of the most critical periods for a crop subjected

\footnotetext{
*These two authors contributed equally to this work.

"Corresponding author.
}

How to cite this paper: Nasri, N., Saïdi, I., Kaddour, R. and Lachaâl, M. (2015) Effect of Salinity on Germination, Seedling Growth and Acid Phosphatase Activity in Lettuce. American Journal of Plant Sciences, 6, 57-63. 
to salinity. Salt stress has been shown to decrease the germination percentage and germination rate of some crops [2]. Soil salinity may influence the germination of seeds either by creating an osmotic potential external to the seed preventing water uptake, or the toxic effects of $\mathrm{Na}^{+}$and $\mathrm{Cl}^{-}$ions on germinating seed [3]. Salt and osmotic stresses are responsible for both inhibition or delayed seed germination and seedling establishment [4]. Seed germination, seedling emergence and early survival are particularly sensitive to substrate salinity [5]. Salt stress affects germination percentage, germination rate and seedling growth in different ways depending on plant species [6]. Germination and seedling growth are reduced in saline soils with varying responses for species and cultivars [7]. Lettuce was determined to be moderately salt sensitive relative to other species [8]. Against these stresses, plants adapt themselves by different mechanisms including change in morphological and developmental pattern as well as physiological and biochemical responses [9]. Adaptation to all these stresses is associated with metabolic adjustments that lead to the modulation of different enzymes [10] [11]. Among these enzymes are phosphatases, which are believed to be important for many physiological processes, including regulation of soluble phosphorous (Pi) [11]. From seeds and seedlings, the physiological function of the acid phosphatases is to provide inorganic phosphate to the growing plant during germination, and many different phosphate esters of sugars and substrates stored in the seed and seedling need to be hydrolyzed during germination and growth [12]. Acid phosphatase activity is known to contribute to resistance under salt and water stress by maintaining a certain level of inorganic phosphate [13]. The present study was designed to study the effect of salinity on seed germination, seedling growth and acid phosphatase activities in Romaine and Vista. These two varieties were selected as representatives of different lettuce genotypes with varying salt tolerance, based on initial germination test under increased $\mathrm{NaCl}$ concentrations $(0-150 \mathrm{mM})$ [14].

\section{Materials and Methods}

The seeds of the two lettuce varieties (Romaine and Vista) used in this investigation were provided by the Seed Laboratory of the Tunisian Ministry of Agriculture. Germination process was conducted as described in previous works [14]. Three parameters of germination were determined which includes: 1) final germination percentage; 2) Germination rate: is a measure of rapidity of germination, with lower values indicating faster germination. It is calculated as follows: GR $=\left(n_{1} t_{1}\right)+\left(n_{2} t_{2}\right)+\ldots \ldots .+\left(n_{x} t_{x}\right) / X n$ where $n_{1}$ is the number of germinates at the first day of germination, $t_{1}$ is the days from start to fist germination, and $\mathrm{Xn}$ is the total number of seeds germinated [15]; 3) Mean Daily Germination MDG = Final germination percentage/number of days to final germination [15]. Regarding morphological studies root length, shoot length, fresh weight and dry weight were measured after 4 days. For biochemical study acid phosphatase activities [16] was analysed from physiologically active root, shoot and cotyledons from different treatments and was carried out as previously described [17].

Statistical analysis including Analysis of variance (ANOVA), Duncan's multiple range test was performed to study the significance of different salinity gradient on different parameters studied. Values were calculated at the $\mathrm{p} \leq 0.05$ probability level.

\section{Results}

To evaluate the effects of salinity on germination three parameters namely: germination percentages (GP), germination rate (GR) and mean daily germination (MDG) were examined. Analysis of variance revealed significant differences among lettuce varieties at germination stage. Germination percentage, rate of germination and mean daily germination (MDG) were strongly decreased with salt stress in Vista variety (Table 1). However, in Romaine variety, the germination percentage (GP) and MDG were not affected by $\mathrm{NaCl} 100 \mathrm{mM}$ but germination rate was diminished by $30 \%$ at $100 \mathrm{mM} \mathrm{NaCl}$ (Table 1). The effect of salt on growth parameters demon-

Table 1. Effect of salinity ( $\mathrm{NaCl} 100 \mathrm{mM})$ on germination percentages (GP), germination rate (GR) and mean daily germination (MDG) of two lettuce varieties (Romaine and Vista).

\begin{tabular}{ccccccc}
\hline & \multicolumn{2}{c}{ Germination \% } & \multicolumn{2}{c}{ Germination Rate (GR) } & \multicolumn{2}{c}{ Mean Daily Germination (MDG) } \\
\hline NaCl (mM) & $\mathbf{0}$ & $\mathbf{1 0 0}$ & $\mathbf{0}$ & $\mathbf{1 0 0}$ & $\mathbf{0}$ & $\mathbf{1 0 0}$ \\
Romaine & 100 & 100 & 1.92 & 1.37 & 6.25 & 6 \\
Vista & 100 & 56 & 1.97 & 1.16 & 6 & 3 \\
\hline
\end{tabular}


strated that seedling biomass did not differ significantly between the two varieties in the absence of salt (Figure 1). In the presence of $100 \mathrm{mM} \mathrm{NaCl}$, seedling growth was considerably diminished in Romaine and Vista during 4 days of growth. Root growth was more affected by salt than was shoot growth. Root elongation was still more sensitive to salt inhibition then shoot length in two lettuce (Figure 2).
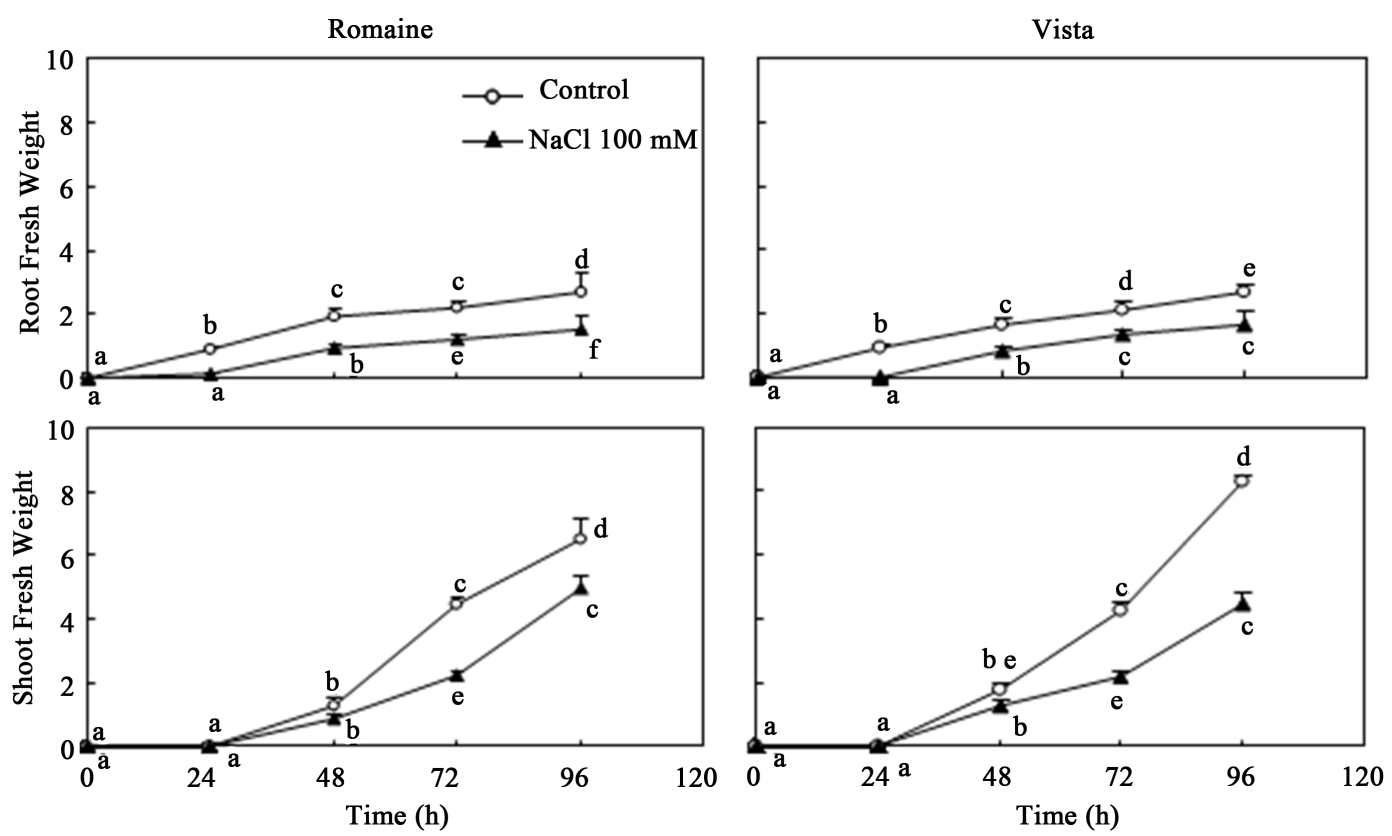

Figure 1. Effect of salinity $(\mathrm{NaCl} 100 \mathrm{mM})$ on root and shoot fresh weight in two lettuce varieties (Romaine and Vista). Values are means of six replicates \pm SD. Means not sharing a common letters (a, b, c, d, e, or f) are significantly different $(\mathrm{p} \leq 0.05)$ as assessed by Duncan's multiple range tests.
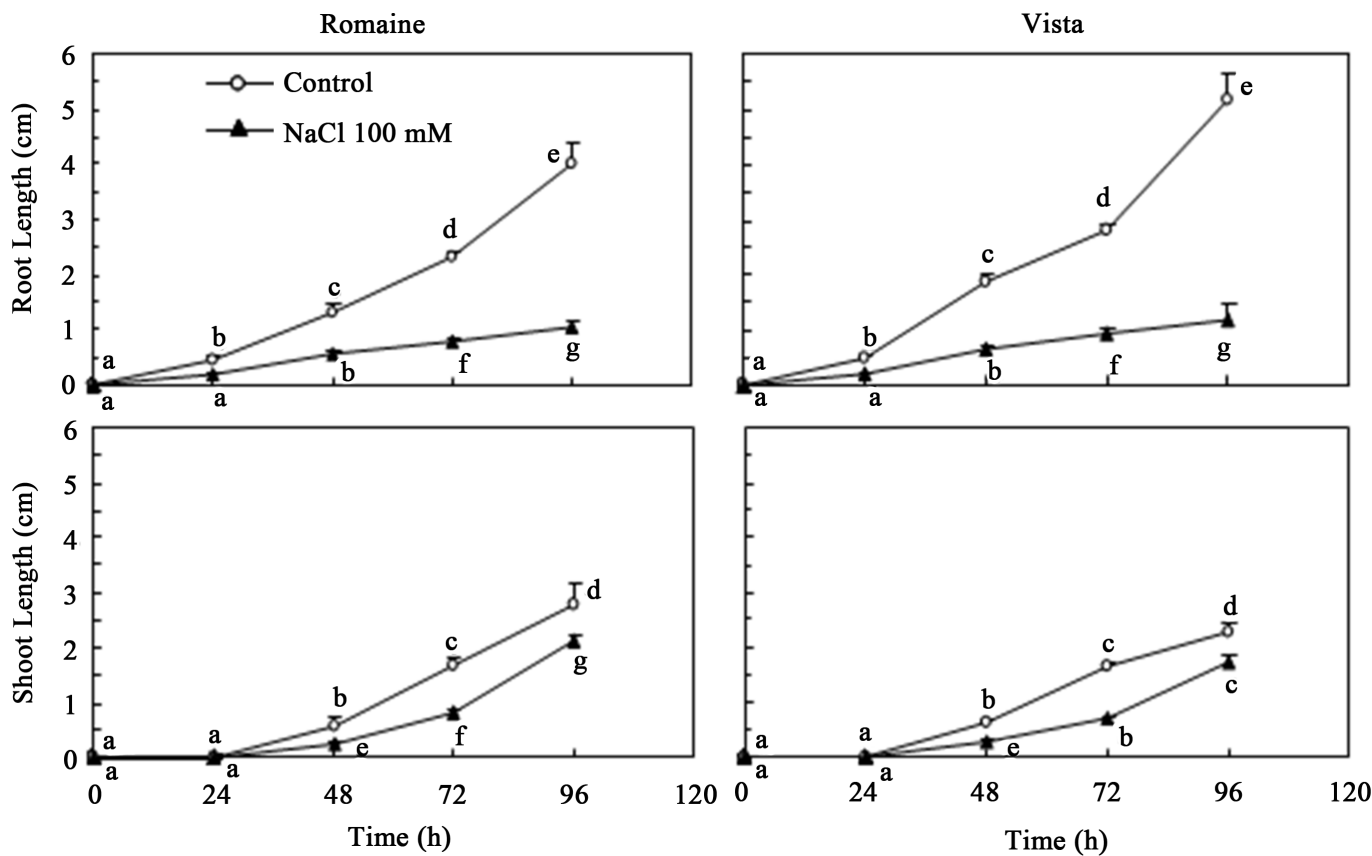

Figure 2. Effect of salinity ( $\mathrm{NaCl} 100 \mathrm{mM}$ ) on root and shoot length in two lettuce varieties (Romaine and Vista). Values are means of six replicates \pm SD. Means not sharing a common letters (a, b, c, d, e, f, or g) are significantly different $(\mathrm{p} \leq 0.05)$ as assessed by Duncan's multiple range tests. 
In root, shoot and cotyledons, acid phosphatase activity (APA) increased with time of germination (Figure 3). Independently of treatment, the highest values of APA are stored in the cotyledons. In the former organs, it increased with time and reached after $96 \mathrm{~h}$ of germination, values 2 and 4 times higher than those of dry seeds, respectively, in Romaine and Vista. In the presence of $100 \mathrm{mM} \mathrm{NaCl}$, acid phosphatase activity remained comparable to controls, at root and shoot and it is significantly decreased in the cotyledons from $24 \mathrm{~h}$ of imbibitions then reaches values comparable to the control after $48 \mathrm{~h}$ of germination in Romaine variety (Figure 3). In sensitive variety Vista, this enzyme activity was almost completely inhibited by salt stress in root and cotyledons and reached comparable to control in shoot (Figure 3).

\section{Discussion}

Germination percentage was significantly decreased by salt stress in lettuce Vista variety. Many researchers have been reported similar results [18] [19]. It observed that, in all of cultivars there was a decrease in germi-
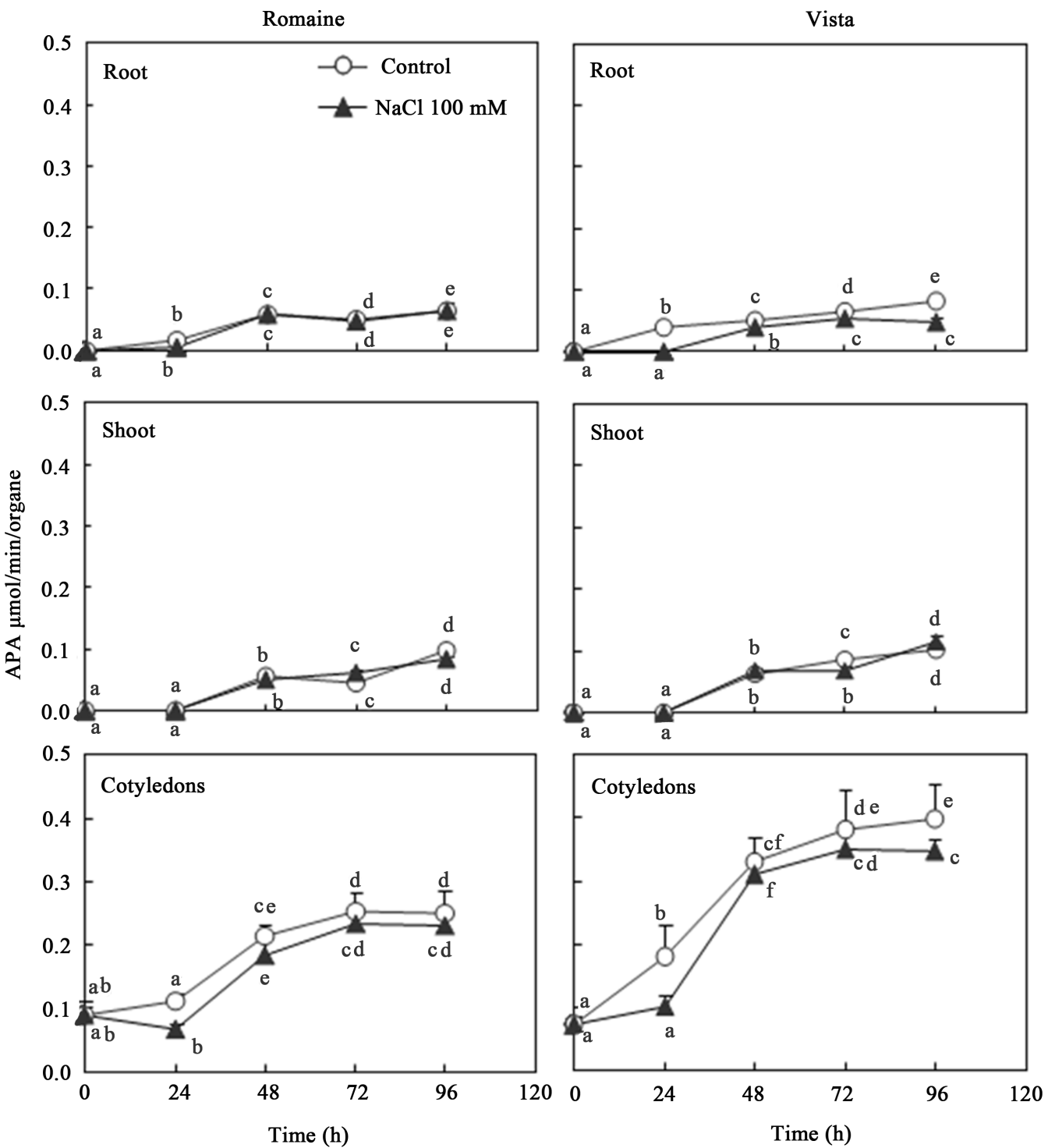

Figure 3. Acid phosphatase activity during germination in root, shoot and cotyledons of two lettuce varieties (Romaine and Vista) after imbibitions with distilled water (Control) or salt solution ( $\mathrm{NaCl}, 100 \mathrm{mM}$ ). Values are means of six replicates \pm SD. Means not sharing a common letters (a, b, c, d, e, or f) are significantly different $(\mathrm{p} \leq 0.05)$ as assessed by Duncan's multiple range tests. 
nation percentage due to salinity increment. Germination rate was decreased by salinity in two lettuce varieties. This agreed with the results of [20] in wheat; [21] in safflower and [22] in Physalis. The decrease in germination rate particularly under drought and salt stress conditions may be due to the fact that seeds seemingly develop an osmotically enforced "dormancy" under water stress conditions. This may be an adaptive strategy of seeds to prevent germination under stressful environment thus ensuring proper establishment of the seedlings [23]. The mean daily germination decreased with salt stress in Vista variety. The findings agree with those observed by [24], who demonstrated that increasing the salinity could decrease germination index, mean daily germination and germination rate.

Salinity caused a significant reduction on root length and shoot length. The results demonstrated that, response of root length to salt stress was more severe than shoot length (Figure 2). This is in agreement with previous reports in lentil [25], Wheat [26], Sorghum bicolor [27]. The reduction in root and shoot development may be due to toxic effects of the higher level of $\mathrm{NaCl}$ concentration as well as unbalanced nutrient uptake by the seedlings. Decrease of growth in root and shoot can be related to $\mathrm{NaCl}$ toxicity and disproportion in nutrient absorption by seedlings. Salt stress caused a decrease in the fresh weight and dry weight of shoot and root. This reduction was relatively depended on shoot or root lengths. [22] demonstrated that salt stress significantly decreased the plant fresh and dry weight of Physalis species. Datta et al. [19] showed that different level of salinity significantly affected the growth attributes by reducing the biomass and length of root and shoot.

In order to gain further insight into the physiological changes occurring during stress conditions, we studied acid phosphatase activities in lettuce seedlings. In our study acid phosphatase activity is stimulated by salinity in salt tolerant variety Romaine and decreased in salt sensitive during germination stage. Salt stress has also been reported to enhance acid phosphatase activity in sorghum and Pearl millet seeds [28] [29]. It may be due to fact that under conditions of stress, growth is restricted and delivery of phosphate is impaired, thus resulting in the activation of the cellular phosphatases that release soluble phosphate from its insoluble compounds inside or outside of the cells thereby modulates osmotic adjustment by free phosphate uptake mechanism [30]. Higher activities of phosphatases enzymes under salt stress conditions in tolerant varieties suggest their direct role in maintaining the much higher energy requirement with the cell to cope with adverse effects of salinity [31].

\section{Conclusion}

The results of this study suggest that salinity reduces seed germination and acid phosphatase activities in salt sensitive lettuce variety Vista. In salt tolerant variety higher germination development and increase in acid phosphatase activity were evaluated at germination stage under salt stress ( $\mathrm{NaCl} 100 \mathrm{mM}$ ). According to the germination parameters and acid phosphatase activity obtained from salt stress conditions, Romaine has higher performance than Vista variety at germination stage. Further research is necessary to identify the molecular mechanism involved in acid phosphatase genes inducing salt tolerance in lettuce seedlings.

\section{References}

[1] Neumann, P.M. (1995) Inhibition of Root Growth by Salinity Stress: Toxicity or an Adaptive Biophysical Response? In: Baluska, F., Ciamporova, M. and Gasparikova, O., Eds., Structure and Function of Roots, Kluwer Academic Publishers, 299-304.

[2] Yildirim, E., Dursun, A., Guvenc, I. and Kumlay, A. (2002) The Effects of Different Salt, Biostimulant and Temperature Levels on Seed Germination of Some Vegetable Species. Acta Agrobotanica, 55, 75-80. http://dx.doi.org/10.5586/aa.2002.045

[3] Khajeh-Hosseini, M., Powell, A.A. and Bingham, I.J. (2003) The Interaction between Salinity Stress and Seed Vigour during Germination of Soybean Seeds. Seed Sciences Technology, 31, 715-725. http://dx.doi.org/10.15258/sst.2003.31.3.20

[4] Almansouri, M., Kinet, J.M. and Lutts, S. (2001). Effect of Salt and Osmotic Stresses on Germination in Durum Wheat (Triticum durum Desf.). Plant and Soil, 231, 243-254. http://dx.doi.org/10.1023/A:1010378409663

[5] Baldwin, A.H., McKee, K.L. and Mendelssohn, I.A. (1996) The Influence of Vegetation, Salinity, and Inundation on Seed Banks of Oligohaline Coastal Marshes. American Journal Botany, 83, 470-479. http://dx.doi.org/10.2307/2446216

[6] Ungar, I. (1996) Effect of Salinity on Seed Germination, Growth, and Ion Accumulation of Atriplex patula Chenopodiaceae. American Journal of Botany, 83, 604-607. http://dx.doi.org/10.2307/2445919 
[7] Hampson, C. and Simpson, G. (1990) Effects of Temperature, Salt, and Osmotic Potential on Early Growth of Wheat Triticum aestivum. I. Germination. Canadian Journal of Botany, 68, 524-528. http://dx.doi.org/10.1139/b90-072

[8] Shannon, M.C. and Grieve, C.M. (1999) Tolerance of Vegetable Crops to Salinity. Scientia Horticulturae, 78, 5-38. http://dx.doi.org/10.1016/S0304-4238(98)00189-7

[9] Bohnert, H.J., Nelson, D.E. and Jensen, R.G. (1995) Adaptations to Environmental Stresses. The Plant Cell, 7, 10991111. http://dx.doi.org/10.1105/tpc.7.7.1099

[10] Yan, X., Liao, H., Trull, M.C., Beebe, S.E. and Lynch, J.P. (2001) Induction of Major Leaf Acid Phosphatase Does Not Confer Adaptation to Low Phosphorus Avaibility. Plant Physiology, 125, 1901-1911. http://dx.doi.org/10.1104/pp.125.4.1901

[11] Ehsanpour, A.A. and Amini, F. (2003) Effect of Salt and Drought Stress on Acid Phosphatase Activities in Alfalfa Medicago sativa L. Explants under in Vitro Culture. African Journal of Biotechnology, 2, 133-135.

[12] Hoehamer, C.F., Mazur, C.S. and Wolfe, N.L. (2005) Purification and Partial Characterization of an Acid Phosphatase from Spirodela oligorrhiza and Its Affinity for Selected Organophosphate Pesticides. Journal of Agricultural and Food Chemistry, 53, 90-97. http://dx.doi.org/10.1021/jf040329u

[13] Olmos, E. and Hellin, E. (1997) Cytochemical Localization of ATPase Plasma Membrane and Acid Phosphatase by Cerium Based in a Salt-Adapted Cell Line of Pisum sativum. Journal of Experimental Botany, 48, 1529-1535. http://dx.doi.org/10.1093/jxb/48.8.1529

[14] Nasri, N., Kaddour, R., Rabhi, M., Plassard, C. and Lachaâl, M. (2011) Effect of Salinity on Germination, Phytase Activity and Phytate Content in Lettuce Seedling. Acta Physiologiae Plantarum, 33, 935-942. http://dx.doi.org/10.1007/s11738-010-0625-4

[15] Rubio-Casal, A.E., Castillo, J.M., Luque, C.J. and Figueroa, M.E. (2003) Influence of Salinity on Germination and Seeds Viability of Two Primary Colonizers of Mediterranean Salt Pans. Journal of Arid Environments, 53, 145-154. http://dx.doi.org/10.1006/jare.2002.1042

[16] Saluja, D., Mihra, S., Lall, S. and Sachar, R.C. (1989) Regulation of Acid Phosphatase by Gibberellic Acid in Embryo-Less Half-Seeds of Wheat. Plant Science, 62, 1-9. http://dx.doi.org/10.1016/0168-9452(89)90182-9

[17] Nasri, N., Kaddour, R., Mahmoudi, H., Baâtour, O., Bouraoui, N. and Lachaâl, M. (2011) The Effect of Osmopriming on Germination, Seedling Growth and Phosphatase Activities of Lettuce under Saline Condition. African Journal of Biotechnology, 10, 14366-14372.

[18] Jeannette, S., Craig, R. and Iynch, J.P. (2002) Salinity Tolerance of Phaseolus Species during Germination and Early Seedling Growth. Crop Science, 42, 1584-1594. http://dx.doi.org/10.2135/cropsci2002.1584

[19] Datta, J.K., Nag, S., Banerjee, A. and Mondal, N.K. (2009) Impact of Salt Stress on Five Varieties of Wheat Triticum aestivum L. Cultivars under Laboratory Condition. Journal of Applied Sciences and Environmental Management, 13, 93-97.

[20] Gholamin, R. and Khayatnezhad, M. (2010) Effects of Polyethylene Glycol and NaCl Stress on Two Cultivars of Wheat Triticum durum at Germination and Early Seeding Stages. American-Eurasian Journal of Agricultural and Environmental Sciences, 9, 86-90.

[21] Mostafavi, K. (2011) An Evaluation of Safflower Genotypes Carthamus tinctorius L. Seed Germination and Seedling Characters in Salt Stress Conditions. African Journal of Agricultural Research, 6, 1667-1672.

[22] Yildirim, E., Karlidag, H. and Dursun, A. (2011) Salt Tolerance of Physalis during Germination and Seedling Growth. Pakistan Journal of Botany, 43, 2673-2676.

[23] Gill, P.K., Sharma, A.D., Singh, P. and Bhullar, S.S. (2003) Changes in Germination, Growth and Soluble Sugar Contents of Sorghum bicolor L. Moench Seeds under Various Abiotic Stresses. Plant Growth Regulation, 40, 157-162. http://dx.doi.org/10.1023/A:1024252222376

[24] Nasr, S.M.H., Parsakhoo, A., Skandari, S., Gojani, H.J. and Koohi, S.K.S. (2012) Investigation of Salinity Tolerance in Dodonaea viscosa L. Journal of Applied Biological Sciences, 6, 31-36.

[25] Ashraf, M. and Waheed, A. (1993) Responses of Some Local/Exotic Accessions of Lentil (Lens culinaris Medic.) to Salt Stress. Journal of Agronomy and Crop Science, 170, 103-112. http://dx.doi.org/10.1111/j.1439-037X.1993.tb01063.x

[26] Akbarimoghaddam, H., Galavi, M., Ghanbari, A. and Panjehkeh, N. (2011) Salinity Effects on Seed Germination and Seedling Growth of Bread Wheat Cultivars. Trakia Journal of Sciences, 9, 43-50.

[27] El Naim, A.M., Khawla, E.M., Ibrahim, E.A. and Suleiman, N.N. (2012) Impact of Salinity on Seed Germination and Early Seedling Growth of three Sorghum (Sorghum biolor L. Moench) Cultivars. Journal of Science and Technology, 2, 16-20.

[28] Jain, A., Sharma, A.D. and Singh, K. (2004) Plant Growth Hormones and Salt Stress-Mediated Changes in Acid and 
Alkaline Phosphatase Activities in the Pearl Millet Seeds. International Journal of Agriculture and Biology, 6, 960963.

[29] Sharma, A.D., Thakur, M., Rana, M. and Singh, K. (2004) Effect of Plant Growth Hormones and Abiotic Stresses on Germination, Growth and Phosphatase Activities in Sorghum bicolor L. Moench Seeds. African Journal of Biotechnology, 3, 308-312.

[30] Fincher, G.B. (1989) Molecular and Cellular Biology Association with Endosperm Mobilization in Germination Cereal Grains. Annual Review of Plant Physiology and Plant Molecular Biology, 40, 305-346. http://dx.doi.org/10.1146/annurev.pp.40.060189.001513

[31] Dubey, R.S. and Sharma, K.N. (1990) Behaviour of Phosphatases in Germinating Rice in Relation to Salt Tolerance. Plant Physiology and Biochemistry, 28, 17-26. 
Scientific Research Publishing (SCIRP) is one of the largest Open Access journal publishers. It is currently publishing more than 200 open access, online, peer-reviewed journals covering a wide range of academic disciplines. SCIRP serves the worldwide academic communities and contributes to the progress and application of science with its publication.

Other selected journals from SCIRP are listed as below. Submit your manuscript to us via either submit@scirp.org or Online Submission Portal.
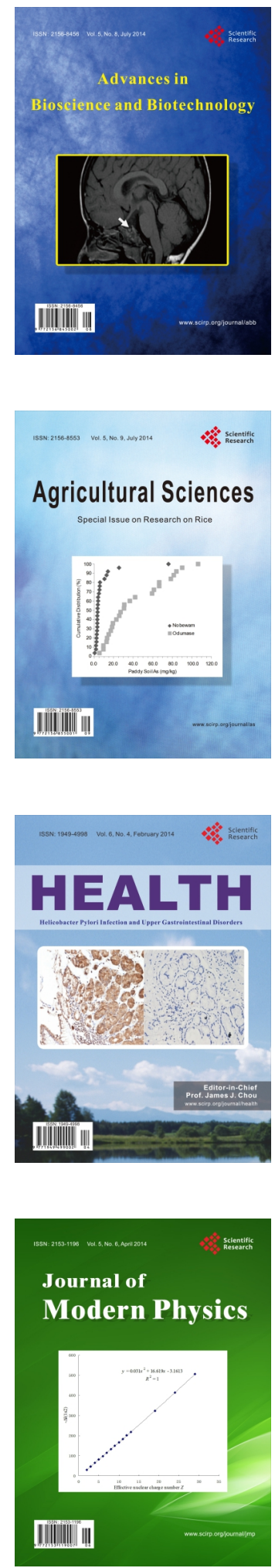
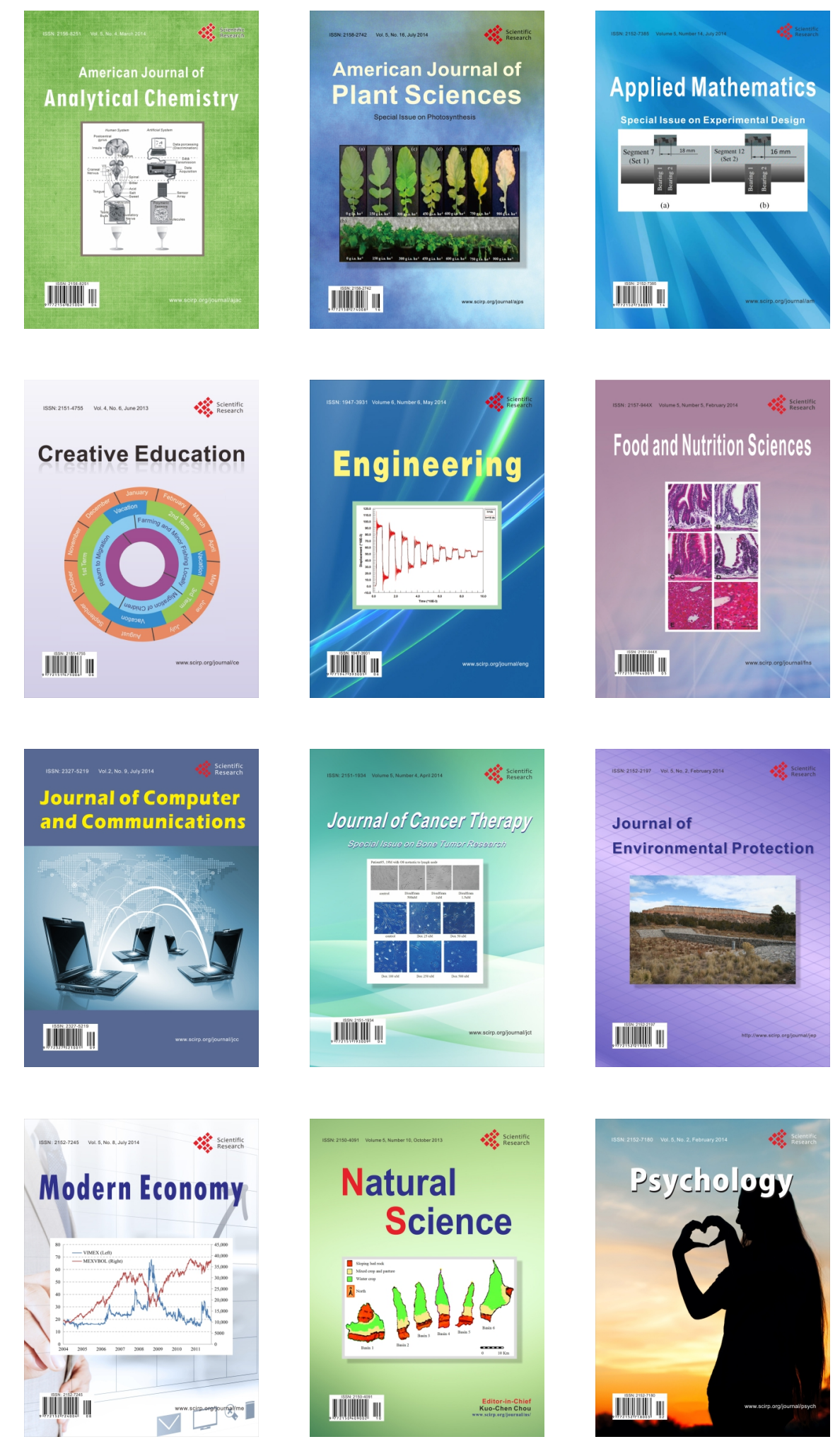